\title{
Cisplatin combined with hyperthermia kills HepG2 cells in intraoperative blood salvage but preserves the function of erythrocytes"
}

\author{
Jin-ting YANG ${ }^{1}$, Li-hui TANG ${ }^{1}$, Yun-qing LIU $^{2}$, Yin WANG ${ }^{2}$, \\ Lie-ju WANG ${ }^{2}$, Feng-jiang ZHANG ${ }^{1}$, Min YAN ${ }^{\dagger 1}$ \\ ( ${ }^{1}$ Department of Anesthesiology, the Second Affiliated Hospital, School of Medicine, Zhejiang University, Hangzhou 310009, China) \\ ('2Jiangsu Province Key Laboratory of Anesthesiology, Xuzhou Medical College, Xuzhou 221004, China) \\ †E-mail: zryanmin@zju.edu.cn \\ Received Aug. 11, 2014; Revision accepted Jan. 22, 2015; Crosschecked Apr. 10, 2015
}

\begin{abstract}
The safe use of intraoperative blood salvage (IBS) in cancer surgery remains controversial. Here, we investigated the killing effect of cisplatin combined with hyperthermia on human hepatocarcinoma (HepG2) cells and erythrocytes from IBS in vitro. HepG2 cells were mixed with concentrated erythrocytes and pretreated with cisplatin (50, 100 , and $200 \mu \mathrm{g} / \mathrm{ml}$ ) alone at $37^{\circ} \mathrm{C}$ for $60 \mathrm{~min}$ and cisplatin $(25,50,100$, and $200 \mu \mathrm{g} / \mathrm{ml})$ combined with hyperthermia at $42{ }^{\circ} \mathrm{C}$ for $60 \mathrm{~min}$. After pretreatment, the cell viability, colony formation and DNA metabolism in HepG2 and the $\mathrm{Na}^{+}-\mathrm{K}^{+}$-ATPase activity, 2,3-diphosphoglycerate (2,3-DPG) concentration, free hemoglobin $(\mathrm{Hb})$ level, osmotic fragility, membrane phosphatidylserine externalization, and blood gas variables in erythrocytes were determined. Pretreatment with cisplatin $(50,100$, and $200 \mu \mathrm{g} / \mathrm{ml})$ combined with hyperthermia $\left(42{ }^{\circ} \mathrm{C}\right)$ for $60 \mathrm{~min}$ significantly decreased HepG2 cell viability, and completely inhibited colony formation and DNA metabolism when the HepG2 cell concentration was $5 \times 10^{4} \mathrm{ml}^{-1}$ in the erythrocyte $(P<0.01)$. Erythrocytic $\mathrm{Na}^{+}-\mathrm{K}^{+}$-ATPase activity, 2,3-DPG level, phosphatidylserine externalization, and extra-erythrocytic free $\mathrm{Hb}$ were significantly altered by hyperthermia plus high concentrations of cisplatin $(100$ and $200 \mu \mathrm{g} / \mathrm{ml})(P<0.05)$, but not by hyperthermia plus $50 \mu \mathrm{g} / \mathrm{ml}$ cisplatin $(P>0.05)$. In conclusion, pretreatment with cisplatin $(50 \mu \mathrm{g} / \mathrm{ml})$ combined with hyperthermia $\left(42{ }^{\circ} \mathrm{C}\right)$ for 60 min effectively eliminated HepG2 cells from IBS but did not significantly affect erythrocytes in vitro.
\end{abstract}

Key words: Erythrocytes, HepG2 cells, Intraoperative blood salvage, Cisplatin, Hyperthermia doi:10.1631/jzus.B1400224

Document code: A

CLC number: R735; R457

\section{Introduction}

The use of intraoperative blood salvage (IBS) has increased in recent years. IBS involves suction, collection, filtration, and washes of blood from the surgical field and reinfusion of red cells. The technique has become widely used in a variety of surgical procedures and is highly effective in saving blood and reducing complications (Adias et al., 2006). Onco-

\footnotetext{
Corresponding author

* Project supported by the Scientific Research from Chinese Ministry of Health-Zhejiang Health Department, China (Nos. WKJ2008-2-021 and WKJ2013-2-019)

(ㄹ) ORCID: Jin-ting YANG, http://orcid.org/0000-0003-3859-6340

(c) Zhejiang University and Springer-Verlag Berlin Heidelberg 2015
}

logic surgery is often accompanied by blood loss that requires massive blood transfusion (Kumar et al., 2014). Allogeneic blood transfusion (ABT) is often used for replenishing blood lost in tumor surgery. However, ABT is associated with many complications such as postoperative infection, pulmonary complications, and poor outcomes, especially the promotion of tumor recurrence in oncological surgery (Kumar et al., 2014).

The applicability of IBS in cancer surgery is controversial. Concerns arise from the hypothesis that tumor cells would be present in the shed blood and concentrated during the procedure, and that these tumor cells could lead to diffusion and metastasis 
after reinfusion (Waters et al., 2012). This possible risk of IBS seems to be real on the basis of some reports that tumor cells were found in blood salvaged from patients undergoing gynecological surgery (Catling et al., 2008), and that viability, proliferation capacity, invasiveness, and tumorigenicity were demonstrated in these tumor cells from the surgical field (Hansen et al., 1995). Whether tumor cells in the shed blood have malignant potential is uncertain, but eliminating tumor cells from IBS before reinfusion is safer for patients.

Leukoreduction filters and irradiation are the two commonly accepted ways of removing tumor cells from salvaged blood (Edelman et al., 1996; Catling et al., 2008), but their effects on tumor cells $\left(>10^{4}\right)$ in the salvaged blood are questionable (Waters and Donnenberg, 2009). Gamma irradiation (50 Gy) is also useful for reducing tumor cell contamination from IBS (Hansen et al., 1999). However, irradiation may not be available because the use of irradiators is not popular in most hospitals (Waters and Donnenberg, 2009). Therefore, the development of a relatively cheap and effective alternative method for eliminating tumor cells from salvaged blood might be the key to the implementation of IBS in cancer surgery.

The study of Wu et al. (2006) showed that hyperthermia at $42-47{ }^{\circ} \mathrm{C}$ for 40 min killed tumor cells in a temperature-dependent manner, but also decreased the activity of $\mathrm{Na}^{+}-\mathrm{K}^{+}$-ATPase in erythrocytes. Therefore, the use of hyperthermia needs to be modified before it is used to eliminate tumor cells in IBS. The fact that heat treatment enhances the effect of anti-tumor drugs, such as cisplatin (Sugarbaker, 2007; Harrison et al., 2008), supports the use of hyperthermia in IBS. Recently, it was found that a combination of cisplatin $(200 \mu \mathrm{g} / \mathrm{ml})$ with hyperthermia $\left(42{ }^{\circ} \mathrm{C}, 30 \mathrm{~min}\right)$ inhibited hepatoma cell proliferation in the blood, and did not markedly inhibit the function of erythrocytes (Zhou et al., 2011). However, the concentration of cisplatin in such a combination treatment was too high and needs to be optimized.

The current study was carried out to explore the effect of hyperthermia $\left(42^{\circ} \mathrm{C}\right.$ for 30,60 , or $120 \mathrm{~min}$ ) on eliminating human hepatocarcinoma (HepG2) cells in combination with different doses of cisplatin $(25,50,100$, or $200 \mu \mathrm{g} / \mathrm{ml})$, and to develop an appropriate combined treatment for eliminating HepG2 cells in IBS while preserving erythrocyte functions.

\section{Materials and methods}

\subsection{Ethics statement}

All human experimental protocols were approved by the Ethics Committee of the Second Affiliated Hospital, School of Medicine, Zhejiang University and the Chinese Clinical Trial Register (No. ChiCTR-OCS-13003599). Written informed consents were obtained from 29 cancer patients who were scheduled for liver cancer surgeries. Erythrocytes were collected from the salvaged surgical field blood by Cell Saver5 (Haemonetics Co., Boston, MA, USA). The patients were all informed that the salvaged blood would not be transfused back into them. Concentrated erythrocytes from each patient were randomly divided into three series as described below.

\subsection{Tumor cells}

The HepG2 cell line was obtained from the Shanghai Institute of Cell Biology, China. HepG2 cells were cultured in Dulbecco's modified Eagle medium (DMEM) with 10\% $(0.1 \mathrm{~g} / \mathrm{ml})$ fetal bovine serum (FBS), along with $100 \mathrm{U} / \mathrm{ml}$ penicillin and $100 \mathrm{mg} / \mathrm{ml}$ streptomycin, at $37{ }^{\circ} \mathrm{C}$ in a humidified incubator containing 5\% $\mathrm{CO}_{2}$. All media and FBS were purchased from Gibco (Grand Island, NY, USA). Cell viability was tested using trypan blue. All the cell numbers given in this study refer to viable cells.

\subsection{Experimental protocols}

2.3.1 The first series: determining the effect of hyperthermia on killing HepG2 cells and erythrocytes

HepG2 cells, cultured at $50 \%-60 \%$ confluence, were mixed with erythrocytes, and the final concentration of HepG2 cells was $5 \times 10^{4} \mathrm{ml}^{-1}$ (Hansen et al., 1995). Mixed cells were divided into the following groups: a control group incubated at $37^{\circ} \mathrm{C}$ for $30 \mathrm{~min}$; hyperthermia groups incubated at $42{ }^{\circ} \mathrm{C}$ for 30,60 , or $120 \mathrm{~min}$.

2.3.2 The second series: determining the effect of a combination of cisplatin and hyperthermia for $60 \mathrm{~min}$ on killing HepG2 cells and erythrocytes

Mixed cells were obtained as described above and were divided into the following groups: a control group incubated at $37^{\circ} \mathrm{C}$ for $60 \mathrm{~min}$; cisplatin groups incubated at $37{ }^{\circ} \mathrm{C}$ with cisplatin (Hansoh Pharmaceutical 
Co., Lianyungang, China) at 50, 100, or $200 \mu \mathrm{g} / \mathrm{ml}$ for $60 \mathrm{~min}$; cisplatin in combination with hyperthermia groups incubated at $42{ }^{\circ} \mathrm{C}$ with cisplatin at $25,50,100$, or $200 \mu \mathrm{g} / \mathrm{ml}$ for $60 \mathrm{~min}$.

2.3.3 The third series: determining the effect of a combination of cisplatin and hyperthermia for $30 \mathrm{~min}$ on killing HepG2 cells and erythrocytes

Mixed cells were divided into the following groups: a control group incubated in $37^{\circ} \mathrm{C}$ for $30 \mathrm{~min}$; cisplatin groups incubated at $37{ }^{\circ} \mathrm{C}$ with cisplatin at 100 or $200 \mu \mathrm{g} / \mathrm{ml}$ for $30 \mathrm{~min}$; cisplatin in combination with hyperthermia groups incubated at $42{ }^{\circ} \mathrm{C}$ with cisplatin at 100 or $200 \mu \mathrm{g} / \mathrm{ml}$ for $30 \mathrm{~min}$.

\subsection{Isolation of tumor cells}

After treatment, HepG2 cells were isolated from the erythrocyte using a single-step density gradient centrifugation of Percoll (GE Healthcare Bio-Sciences AB, Uppsala, Sweden) (Hansen et al., 1995). The density of Percoll was $1.063 \mathrm{~g} / \mathrm{ml}$, which provides a significantly greater separation of cancer cells from the blood with maximal reduction in leukocyte contamination (Hansen et al., 1995). The separated HepG2 cells and erythrocytes were evaluated as follows.

\subsection{MTT assay}

After the separated HepG2 cells were seeded on 96-well plates in quintuplicate for $24 \mathrm{~h}$ at $37^{\circ} \mathrm{C}$ in a humidified incubator containing $5 \% \mathrm{CO}_{2}$, cell viability was measured using 3-(4,5-dimethylthiazol-2-yl)-2, 5-diphenyltetrazolium bromide (MTT; Sigma-Aldrich Inc., St. Louis, MO, USA). The percentage of viable cells for each group was determined by measuring absorbance (optical density) at $490 \mathrm{~nm}\left(\mathrm{OD}_{490}\right)$ using a microplate reader (BioRad, Hercules, CA, USA) and normalized to the control group.

\subsection{EdU incorporation assay}

After the separated HepG2 cells were seeded on 96-well plates in triplicate for $24 \mathrm{~h}$ at $37{ }^{\circ} \mathrm{C}$ in a humidified incubator containing $5 \% \mathrm{CO}_{2}$, they were incubated for $2 \mathrm{~h}$ with $50 \mu \mathrm{mol} / \mathrm{L}$ 5-ethynyl-2'deoxyuridine (EdU; RiboBio, Guangzhou, China), according to the manufacturer's instruction, to detect DNA replication. The numbers of EdU-positive cells were counted by Hoechst staining of nuclei.

\subsection{Assay of plate colony formation in HepG2 cells}

After the separated HepG2 cells were seeded on 6-well plates in triplicate for $14 \mathrm{~d}$ at $37{ }^{\circ} \mathrm{C}$ in a humidified incubator containing $5 \% \mathrm{CO}_{2}$, colony formation in HepG2 cells was determined using Giemsa staining (Hansen et al., 1999).

2.8 Assay of 2,3-DPG and free $\mathrm{Hb}$ levels, and $\mathrm{Na}^{+}-\mathrm{K}^{+}$-ATPase activity in erythrocytes

After treatment, erythrocytes were separated from the mixed cells. Free hemoglobin $(\mathrm{Hb})$ and 2,3-diphosphoglycerate (2,3-DPG) levels were determined using Quantitative Human Competitive ELISA kits (Hermes Criterion Biotechnology, Vancouver, Canada). $\mathrm{Na}^{+}-\mathrm{K}^{+}$-ATPase activity in erythrocytes was determined using a commercial kit (Nanjing Jiancheng Bioengineering Institute, Nanjing, China) according to the manufacturer's instructions.

\subsection{Osmotic fragility test in erythrocytes}

After treatment, erythrocytes were separated from the mixed cells. Erythrocyte osmotic fragility analysis was carried out according to the method described by Hasegawa et al. (2012). Briefly, erythrocytes were incubated in a series of $\mathrm{NaCl}$ concentrations ranging from $0.24 \%$ to $0.68 \%$. The absorbance at $540 \mathrm{~nm}$ was measured to indicate $\mathrm{Hb}$ concentration in the supernatant. The erythrocyte group treated with normal saline was used as a negative control ( $0 \%$ hemolysis), while the group treated with distilled water was used as a positive control $(100 \%$ hemolysis).

\subsection{Assay of phospholipid bilayer integrity in erythrocytes}

After treatment, erythrocytes were separated from the mixed cells. The physical integrity of the erythrocyte membrane was evaluated by measuring the amount of extracellular phosphatidylserine stained with fluorescein isothiocyanate-annexin V (BD Biosciences Pharmingen, San Diego, CA, USA) using flow cytometry according to the manufacturer's instructions.

\subsection{Assay of blood gases in the solution of erythrocytes}

After treatment, erythrocytes were separated from the mixed cells. The $\mathrm{K}^{+}$and $\mathrm{Na}^{+}$concentrations, 
$\mathrm{pH}$, and $50 \%$ of the haemes saturated with oxygen $\left(\mathrm{P}_{50}\right)$ of the solution of erythrocytes were measured using an automated blood gas analyzer (Roche Diagnostics Cobas b123, Shanghai, China).

\subsection{Statistical analysis}

Continuous variables were expressed as the mean \pm standard deviation (SD). Phosphatidylserine levels were analyzed by paired Student's $t$-test. Categorical variables were analyzed by chi-square tests. Other data were analyzed by one-way analysis of variance (ANOVA) followed by the Newman-Keuls test. All statistical analyses were performed using GraphPad Prism 5.0 software (GraphPad Software Inc., San Diego, CA, USA). A value of $P<0.05$ was considered to be statistically significant.

\section{Results}

\subsection{Clinical data of patients}

The baseline characteristics of patients, including their tumor types, sex ratio, ages, and clinical data, did not differ significantly among all the experimental series (Table 1).

\subsection{Effects of hyperthermia on inhibiting HepG2 cell survival}

HepG2 cell viability, colony formation, and DNA metabolism were all significantly, but not completely, inhibited by hyperthermia in a timedependent manner $\left(42^{\circ} \mathrm{C}\right.$ for 30,60 , and $\left.120 \mathrm{~min}\right)$ compared with the control group $(P<0.01$; Fig. 1$)$. In addition, we found that cell viability, DNA metabolism, and colony formation in the HepG2 cell line without erythrocytes (data not shown) were slightly decreased, but showed no significant difference compared with those in the HepG2 cell line mixed with erythrocytes under the same hyperthermia, cisplatin, and hyperthermia plus cisplatin treatments.

\subsection{Effects of hyperthermia on erythrocytes}

In erythrocytes, the osmotic fragility, $\mathrm{Na}^{+}-\mathrm{K}^{+}-$ ATPase activity, 2,3-DPG level, free $\mathrm{Hb}$ level, or the blood gas variables were not significantly altered by pretreating with hyperthermia for 30 or $60 \mathrm{~min}$ (Fig. 2 and Table 2). However, extra-erythrocytic $\mathrm{K}^{+}$, free $\mathrm{Hb}$, and osmotic fragility were markedly increased in the group treated with hyperthermia for $120 \mathrm{~min}$ $(P<0.05$ vs. control).

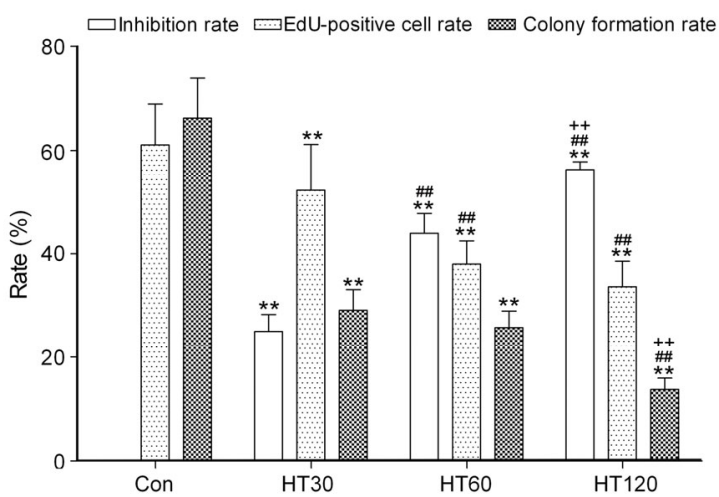

Fig. 1 Effects of hyperthermia on inhibiting HepG2 cell survival

Data are expressed as mean $\pm \mathrm{SD}$, with $n=9$ in each experiment. ${ }^{* *} P<0.01$ vs. control (treated at $37^{\circ} \mathrm{C}$ for $30 \mathrm{~min}$ ); ${ }^{\#} P<0.01$ vs. HT30; ${ }^{++} P<0.01$ vs. HT60. HT30, HT60, and HT120: hyperthermia for 30,60 , and 120 min, respectively

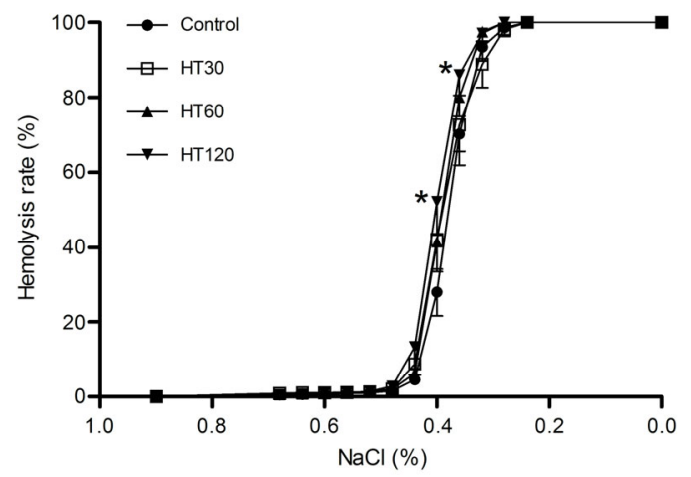

Fig. 2 Effects of hyperthermia on the osmotic fragility of erythrocytes

Data are expressed as mean $\pm \mathrm{SD}$, with $n=9$ in each experiment. ${ }^{*} P<0.05$ vs. control (treated at $37^{\circ} \mathrm{C}$ for $30 \mathrm{~min}$ ). HT30, HT60, and HT120: hyperthermia for 30, 60, and $120 \mathrm{~min}$, respectively

Table 1 Baseline characteristics and clinical data of patients

\begin{tabular}{lccccccc}
\hline Series & $\begin{array}{c}\text { Sex } \\
(\text { male/female })\end{array}$ & $\begin{array}{c}\text { Age } \\
(\text { year })\end{array}$ & $\begin{array}{c}\text { Blood salvaged } \\
(\mathrm{ml})\end{array}$ & $\begin{array}{c}\text { Blood shed } \\
(\mathrm{ml})\end{array}$ & $\begin{array}{c}\text { Liver } \\
\text { cancer }\end{array}$ & \multicolumn{2}{c}{ Receipt in the surgery (ml) } \\
\cline { 7 - 9 } & $5 / 4$ & $62.56 \pm 11.08$ & $135 \pm 126$ & $217 \pm 158$ & 9 & $1625 \pm 518$ & $875 \pm 231$ \\
First & $6 / 4$ & $58.39 \pm 12.41$ & $122 \pm 115$ & $210 \pm 149$ & 10 & $1600 \pm 516$ & $900 \pm 211$ \\
Third & $5 / 5$ & $59.30 \pm 9.44$ & $125 \pm 117$ & $215 \pm 195$ & 10 & $1550 \pm 499$ & $850 \pm 242$ \\
\hline
\end{tabular}

The first series: the effects of hyperthermia on killing HepG2 cells and erythrocytes; the second series: the effects of cisplatin combined with hyperthermia for $60 \mathrm{~min}$ on killing HepG2 cells and erythrocytes; the third series: the effects of cisplatin combined with hyperthermia for 30 min on killing HepG2 cells and erythrocytes. Data are expressed as mean \pm SD, except for sex and liver cancer (number) 
Table 2 Effects of hyperthermia on cell membrane and blood gas variables in erythrocytes

\begin{tabular}{lcccccccc}
\hline Treatment & $\begin{array}{c}\mathrm{Hb} \\
(\mathrm{mg} / \mathrm{ml})\end{array}$ & $\begin{array}{c}\mathrm{P}_{50} \\
(\mathrm{mmHg})\end{array}$ & $\mathrm{pH}$ & $\begin{array}{c}\mathrm{K}^{+} \\
(\mathrm{mmol} / \mathrm{L})\end{array}$ & $\begin{array}{c}\mathrm{Na}^{+} \\
(\mathrm{mmol} / \mathrm{L})\end{array}$ & $\begin{array}{c}\text { ATPase } \\
\left(\mathrm{U} / 10^{7} \text { cells }\right)\end{array}$ & $\begin{array}{c}2,3-\mathrm{DPG} \\
(\mathrm{g} / \mathrm{L})\end{array}$ & $\begin{array}{c}\text { Free Hb } \\
(\mathrm{mg} / \mathrm{ml})\end{array}$ \\
\hline Control & $60.53 \pm 11.61$ & $19.08 \pm 4.96$ & $7.46 \pm 0.13$ & $1.47 \pm 0.53$ & $150.22 \pm 1.11$ & $0.080 \pm 0.018$ & $9.68 \pm 1.77$ & $0.089 \pm 0.004$ \\
HT30 & $60.85 \pm 11.52$ & $20.73 \pm 6.29$ & $7.44 \pm 0.13$ & $1.77 \pm 0.63$ & $150.27 \pm 1.12$ & $0.068 \pm 0.023$ & $9.05 \pm 1.41$ & $0.091 \pm 0.006$ \\
HT60 & $59.90 \pm 10.72$ & $20.14 \pm 6.11$ & $7.42 \pm 0.13$ & $2.01 \pm 0.68$ & $150.11 \pm 1.59$ & $0.067 \pm 0.021$ & $8.47 \pm 1.29$ & $0.091 \pm 0.008$ \\
HT120 & $58.71 \pm 11.52$ & $20.12 \pm 6.08$ & $7.41 \pm 0.13$ & $2.62 \pm 0.75^{* *}$ & $149.63 \pm 1.28$ & $0.059 \pm 0.017$ & $8.07 \pm 1.55$ & $0.098 \pm 0.005^{* *}$ \\
\hline
\end{tabular}

Data are expressed as mean $\pm \mathrm{SD}$, with $n=9$ in each experiment. ${ }^{* *} P<0.01$ vs. control (treated at $37{ }^{\circ} \mathrm{C}$ for 30 min). HT30, HT60, and HT120: hyperthermia for 30,60 , and 120 min, respectively

\subsection{Effects of cisplatin combined with hyperther- mia for 60 min on HepG2 cell survival}

HepG2 cell death was significantly increased and colony formation and DNA metabolism were significantly inhibited in all cisplatin groups compared with the control group $(P<0.01$; Fig. 3$)$. No EdU-positive cell or colony formation was found in HepG2 cells pretreated with a combination of cisplatin $(50,100$, or $200 \mu \mathrm{g} / \mathrm{ml})$ and hyperthermia for 60 min (Fig. 3).

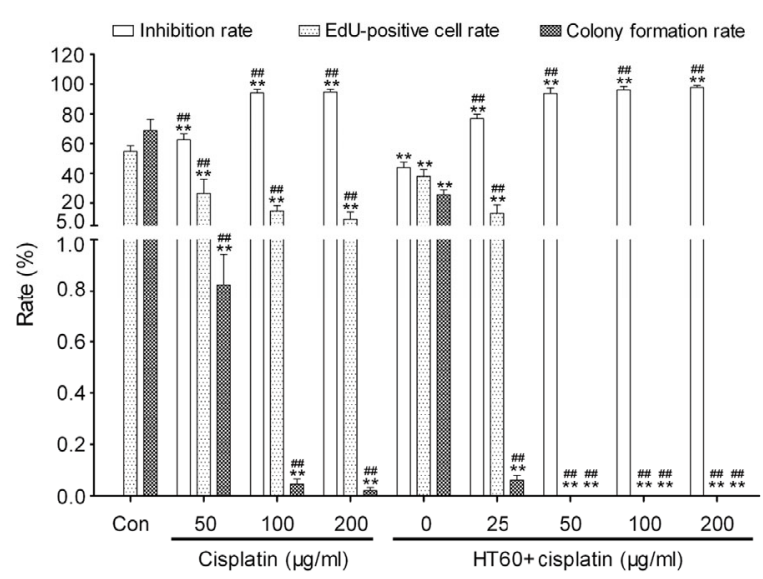

Fig. 3 Effects of cisplatin combined with hyperthermia for 60 min (HT60) on HepG2 cell survival

Data are expressed as mean $\pm \mathrm{SD}$, with $n=10$ in each experiment. ${ }^{* *} P<0.01$ vs. control (treated at $37^{\circ} \mathrm{C}$ for $60 \mathrm{~min}$ ); \# $P<0.01$ vs. HT60

\subsection{Effects of cisplatin combined with hyper- thermia for $60 \mathrm{~min}$ on erythrocytes}

Osmotic fragility, $\mathrm{Na}^{+}-\mathrm{K}^{+}$-ATPase activity, 2,3-DPG, free $\mathrm{Hb}, \mathrm{pH}$ value, and extracellular $\mathrm{K}^{+}$and $\mathrm{Na}^{+}$were all significantly altered by pretreating with a high dose of cisplatin $(200 \mu \mathrm{g} / \mathrm{ml})$ alone and cisplatin (100 or $200 \mu \mathrm{g} / \mathrm{ml}$ ) combined with hyperthermia for $60 \min (P<0.05$ vs. control), but not by a low dose of cisplatin $(50$ or $100 \mu \mathrm{g} / \mathrm{ml})$ alone or cisplatin (25 and
$50 \mu \mathrm{g} / \mathrm{ml}$ ) combined with hyperthermia ( $P>0.05$ vs. control) (Fig. 4 and Table 3). The amount of phosphatidylserine outside of the erythrocyte membranes was not significantly increased by pretreating with cisplatin $(50 \mu \mathrm{g} / \mathrm{ml})$ combined with hyperthermia for 60 min (Fig. 5).

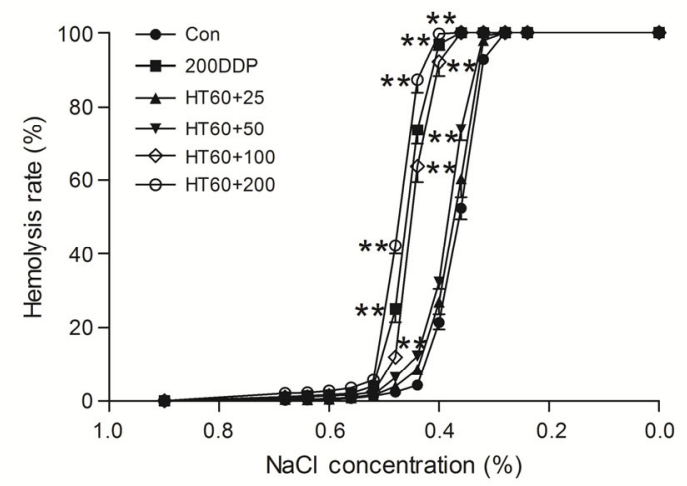

Fig. 4 Effects of cisplatin combined with hyperthermia for $60 \mathrm{~min}$ (HT60) on the osmotic fragility of erythrocytes Data are expressed as mean $\pm \mathrm{SD}$, with $n=10$ in each experiment. ${ }^{* *} P<0.01$ vs. control (treated at $37^{\circ} \mathrm{C}$ for $60 \mathrm{~min}$ ). HT60+25, HT60+50, HT60+100, and HT60+200: 25, 50, 100 , and $200 \mu \mathrm{g} / \mathrm{ml}$ cisplatin combined with hyperthermia for $60 \mathrm{~min}$, respectively. 200DDP: $200 \mu \mathrm{g} / \mathrm{ml}$ cisplatin

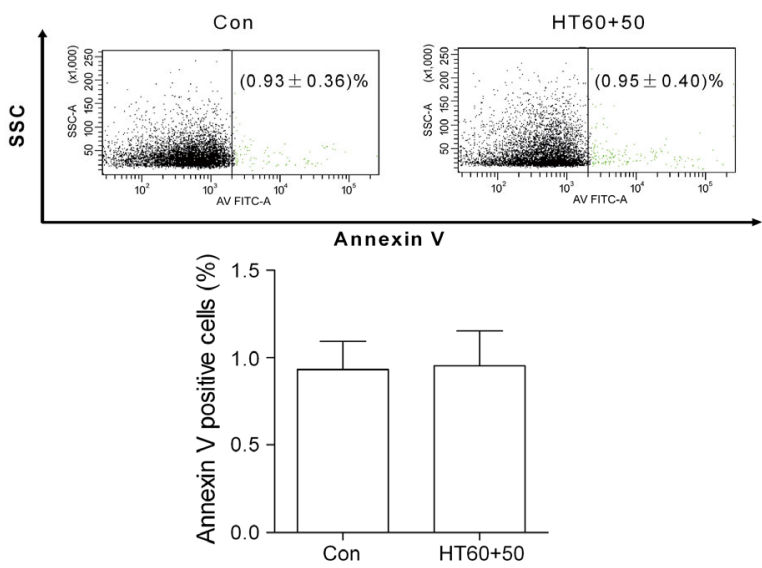

Fig. 5 Effects of cisplatin $(50 \mu \mathrm{g} / \mathrm{ml})$ combined with hyperthermia for 60 min $($ HT60+50) on phosphatidylserine outside of the erythrocyte membranes

The amount of phosphatidylserine outside of the erythrocyte membranes is expressed as the percentage of annexin Vpositive cells in total erythrocytes. Data are expressed as mean $\pm \mathrm{SD}$, with $n=10$ in each experiment 
Table 3 Effects of a combination of cisplatin and hyperthermia for $60 \mathrm{~min}(\mathrm{HT60})$ on cell membrane and blood gas variables in erythrocytes

\begin{tabular}{|c|c|c|c|c|c|c|c|c|}
\hline Treatment & $\begin{array}{c}\mathrm{Hb} \\
(\mathrm{mg} / \mathrm{ml})\end{array}$ & $\begin{array}{c}\mathrm{P}_{50} \\
(\mathrm{mmHg})\end{array}$ & $\mathrm{pH}$ & $\begin{array}{c}\mathrm{K}^{+} \\
(\mathrm{mmol} / \mathrm{L})\end{array}$ & $\begin{array}{c}\mathrm{Na}^{+} \\
(\mathrm{mmol} / \mathrm{L})\end{array}$ & $\begin{array}{c}\text { ATPase } \\
\left(\mathrm{U} / 10^{7} \text { cells }\right) \\
\end{array}$ & $\begin{array}{c}2,3-\mathrm{DPG} \\
(\mathrm{g} / \mathrm{L})\end{array}$ & $\begin{array}{l}\text { Free Hb } \\
(\mathrm{mg} / \mathrm{ml})\end{array}$ \\
\hline Control & $61.68 \pm 2.69$ & $18.58 \pm 8.76$ & $7.44 \pm 0.17$ & $1.43 \pm 0.48$ & $148.71 \pm 2.74$ & $0.078 \pm 0.022$ & $9.67 \pm 1.74$ & $0.089 \pm 0.005$ \\
\hline \multicolumn{9}{|c|}{ Cisplatin $(\mu \mathrm{g} / \mathrm{ml})$} \\
\hline 50 & $59.58 \pm 1.61$ & $19.36 \pm 8.45$ & $7.43 \pm 0.14$ & $1.96 \pm 0.51$ & $152.58 \pm 5.63$ & $0.069 \pm 0.020$ & $8.92 \pm 1.12$ & $0.091 \pm 0.005$ \\
\hline 100 & $58.95 \pm 5.20$ & $21.86 \pm 7.09$ & $7.37 \pm 0.14$ & $2.11 \pm 0.54$ & $153.55 \pm 3.87$ & $0.063 \pm 0.017$ & $8.47 \pm 1.16$ & $0.094 \pm 0.004$ \\
\hline 200 & $58.47 \pm 4.76$ & $16.91 \pm 6.20$ & $7.26 \pm 0.09^{*}$ & $2.42 \pm 0.67^{* *}$ & $154.91 \pm 6.84^{*}$ & $0.055 \pm 0.016^{*}$ & $7.63 \pm 1.22^{*}$ & $0.098 \pm 0.006^{*}$ \\
\hline \multicolumn{9}{|c|}{ HT60+cisplatin $(\mu \mathrm{g} / \mathrm{ml})$} \\
\hline 0 & $59.90 \pm 3.60$ & $19.16 \pm 8.53$ & $7.43 \pm 0.08$ & $1.96 \pm 0.68$ & $150.92 \pm 3.94$ & $0.071 \pm 0.014$ & $8.46 \pm 1.18$ & $0.090 \pm 0.007$ \\
\hline 25 & $59.47 \pm 3.76$ & $19.48 \pm 6.25$ & $7.41 \pm 0.13$ & $1.98 \pm 0.46$ & $150.00 \pm 3.74$ & $0.068 \pm 0.012$ & $8.31 \pm 1.14$ & $0.094 \pm 0.006$ \\
\hline 50 & $59.17 \pm 4.94$ & $19.98 \pm 6.96$ & $7.41 \pm 0.14$ & $2.01 \pm 0.53$ & $153.08 \pm 5.11$ & $0.065 \pm 0.018$ & $8.08 \pm 1.19$ & $0.097 \pm 0.006$ \\
\hline 100 & $58.28 \pm 5.04$ & $17.20 \pm 8.18$ & $7.27 \pm 0.06^{*}$ & $2.33 \pm 0.58^{*}$ & $154.88 \pm 3.27^{*}$ & $0.056 \pm 0.011^{*}$ & $7.60 \pm 1.14^{*}$ & $0.104 \pm 0.008^{* *}$ \\
\hline 200 & $56.47 \pm 6.25$ & $14.72 \pm 8.14$ & $7.23 \pm 0.08^{* *}$ & $2.64 \pm 0.61^{* *}$ & $157.45 \pm 4.28^{* *}$ & $0.049 \pm 0.012^{* *}$ & $7.51 \pm 1.72^{*}$ & $0.106 \pm 0.008^{* *}$ \\
\hline
\end{tabular}

Data are expressed as mean $\pm \mathrm{SD}$, with $n=10$ in each experiment. ${ }^{*} P<0.05,{ }^{* *} P<0.01$ vs. control (treated at $37{ }^{\circ} \mathrm{C}$ for $60 \mathrm{~min}$ )

\subsection{Effects of cisplatin combined with hyper- thermia for 30 min on HepG2 cell survival}

HepG2 cell viability, colony formation, and DNA metabolism were significantly inhibited by pretreating with hyperthermia for $30 \mathrm{~min}$, cisplatin $(100$ or $200 \mu \mathrm{g} / \mathrm{ml})$ alone, and cisplatin (100 or $200 \mu \mathrm{g} / \mathrm{ml}$ ) combined with hyperthermia for $30 \mathrm{~min}$ $(P<0.05$ vs. control; Fig. 6). No EdU-positive cells or colonies were found in HepG2 cells pretreated with cisplatin $(200 \mu \mathrm{g} / \mathrm{ml})$ combined with hyperthermia for 30 min (Fig. 6).

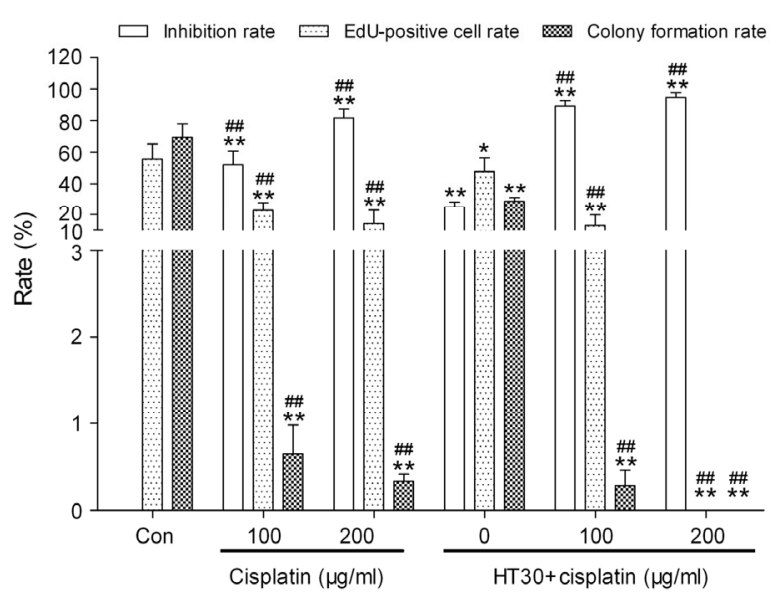

Fig. 6 Effects of cisplatin combined with hyperthermia for 30 min (HT30) on HepG2 cell survival

Data are expressed as mean $\pm \mathrm{SD}$, with $n=10$ in each experiment. ${ }^{*} P<0.05,{ }^{* *} P<0.01$ vs. control (treated at $37{ }^{\circ} \mathrm{C}$ for $30 \mathrm{~min}$ ); ${ }^{\# \#} P<0.01$ vs. HT30

\subsection{Effects of cisplatin combined with hyper- thermia for 30 min on erythrocytes}

Osmotic fragility, $\mathrm{Na}^{+}-\mathrm{K}^{+}$-ATPase activity, 2,3-DPG, free $\mathrm{Hb}, \mathrm{pH}$ value, and extracellular $\mathrm{K}^{+}$and $\mathrm{Na}^{+}$were all significantly altered by pretreating with a high dose of cisplatin $(200 \mu \mathrm{g} / \mathrm{ml})$ combined with hyperthermia for $30 \mathrm{~min}(P<0.05 \mathrm{vs}$. control), but not by other treatments (Fig. 7 and Table 4 ).

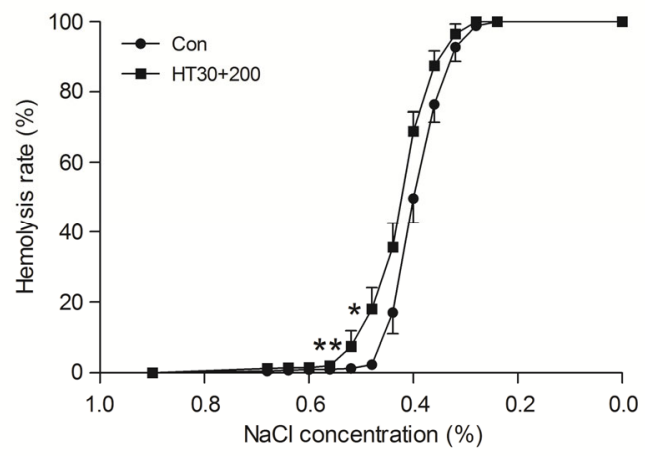

Fig. 7 Effects of cisplatin $(200 \mu \mathrm{g} / \mathrm{ml})$ combined with hyperthermia for $30 \mathrm{~min}(\mathrm{HT30}+200)$ on the osmotic fragility of erythrocytes

Data are expressed as mean $\pm \mathrm{SD}$, with $n=10$ in each experiment. ${ }^{*} P<0.05,{ }^{* *} P<0.01$ vs. control (treated at $37{ }^{\circ} \mathrm{C}$ for $30 \mathrm{~min}$ )

\section{Discussion}

Hepatoma is the third leading cause of death due to cancer worldwide and accounts for more than $50 \%$ 
Table 4 Effects of a combination of cisplatin and hyperthermia for 30 min (HT30) on cell membrane and blood gas variables in erythrocytes

\begin{tabular}{|c|c|c|c|c|c|c|c|c|}
\hline Treatment & $\begin{array}{c}\mathrm{Hb} \\
(\mathrm{mg} / \mathrm{ml})\end{array}$ & $\begin{array}{c}\mathrm{P}_{50} \\
(\mathrm{mmHg})\end{array}$ & $\mathrm{pH}$ & $\begin{array}{c}\mathrm{K}^{+} \\
(\mathrm{mmol} / \mathrm{L}) \\
\end{array}$ & $\begin{array}{c}\mathrm{Na}^{+} \\
(\mathrm{mmol} / \mathrm{L})\end{array}$ & $\begin{array}{c}\text { ATPase } \\
\left(\mathrm{U} / 10^{7} \text { cells }\right) \\
\end{array}$ & $\begin{array}{c}\text { 2,3-DPG } \\
(\mathrm{g} / \mathrm{L})\end{array}$ & $\begin{array}{l}\text { Free } \mathrm{Hb} \\
(\mathrm{mg} / \mathrm{ml})\end{array}$ \\
\hline Control & $62.20 \pm 15.87$ & $20.28 \pm 7.81$ & $7.45 \pm 0.11$ & $1.46 \pm 0.56$ & $148.28 \pm 0.46$ & $0.080 \pm 0.012$ & $9.67 \pm 2.09$ & $0.089 \pm 0.008$ \\
\hline \multicolumn{9}{|c|}{ Cisplatin $(\mu \mathrm{g} / \mathrm{ml})$} \\
\hline 100 & $61.93 \pm 15.66$ & $25.78 \pm 2.88$ & $7.42 \pm 0.09$ & $1.91 \pm 0.51$ & $149.33 \pm 1.23$ & $0.069 \pm 0.015$ & $8.94 \pm 2.07$ & $0.092 \pm 0.008$ \\
\hline 200 & $60.53 \pm 14.18$ & $27.40 \pm 3.59$ & $7.29 \pm 0.14^{*}$ & $2.05 \pm 0.46$ & $150.25 \pm 1.14$ & $0.061 \pm 0.022$ & $8.17 \pm 2.20$ & $0.096 \pm 0.008$ \\
\hline \multicolumn{9}{|c|}{ HT30+cisplatin $(\mu \mathrm{g} / \mathrm{ml})$} \\
\hline 0 & $63.55 \pm 14.03$ & $25.70 \pm 3.99$ & $7.44 \pm 0.14$ & $1.74 \pm 0.49$ & $148.63 \pm 0.64$ & $0.068 \pm 0.032$ & $9.09 \pm 2.13$ & $0.091 \pm 0.005$ \\
\hline 100 & $61.73 \pm 14.03$ & $27.00 \pm 3.71$ & $7.35 \pm 0.16$ & $2.12 \pm 0.68$ & $149.95 \pm 1.16$ & $0.059 \pm 0.023$ & $8.01 \pm 2.10$ & $0.099 \pm 0.008^{*}$ \\
\hline 200 & $59.65 \pm 15.69$ & $27.90 \pm 3.15$ & $7.25 \pm 0.12^{* *}$ & $2.29 \pm 0.60^{*}$ & $155.45 \pm 1.13^{*}$ & $0.051 \pm 0.015^{*}$ & $7.71 \pm 1.79$ & $0.102 \pm 0.009^{* *}$ \\
\hline
\end{tabular}

Data are expressed as mean $\pm \mathrm{SD}$, with $n=10$ in each experiment. ${ }^{*} P<0.05,{ }^{* *} P<0.01$ vs. control (treated at $37^{\circ} \mathrm{C}$ for 30 min)

of cancer deaths in China (Jemal et al., 2010). The use of IBS is necessary in hepatoma surgery because of the shortage of allogeneic blood supply in China. However, how to remove tumor cells effectively from IBS without injuring erythrocytes remains controversial. In the current work, we found that hyperthermia $\left(42{ }^{\circ} \mathrm{C}\right)$ alone was not enough to completely kill HepG2 cell lines, but a combination of cisplatin $(50 \mu \mathrm{g} / \mathrm{ml})$ and hyperthermia $\left(42{ }^{\circ} \mathrm{C}\right)$ for $60 \mathrm{~min}$ effectively purged HepG2 cell lines without significantly injuring the mixed erythrocytes. However, this approach of purging tumor cells from salvaged blood needs to be tested in some form of preclinical in vivo system before considering its application in cancer surgery.

It is known that hyperthermia damages the fluidity and stability of cellular membranes, inactivates membrane proteins, and ultimately induces cell death (Hildebrandt et al., 2002). Furthermore, it causes reorganization of the cytoskeleton, degradation of RNA and DNA, and a reduction in protein synthesis, all of which damage the tumor vasculature and kill tumor cells (Hildebrandt et al., 2002). Because of these effects, hyperthermia is commonly used as an auxiliary method to kill tumor cells in vitro. For hyperthermia, the American Association of Blood Banks suggested that the maximum temperature of warmed blood should be limited to $42{ }^{\circ} \mathrm{C}$ (Herron et al., 1997). In the current work, we applied hyperthermia $\left(42^{\circ} \mathrm{C}\right)$ for 30,60 , and $120 \mathrm{~min}$ and found that cell viability, DNA metabolism, and colony formation in $\mathrm{HepG} 2$ cells were inhibited in a time-dependent manner. However, extra-erythrocytic $\mathrm{K}^{+}$and free $\mathrm{Hb}$ concentrations were both increased significantly by hyperthermia for $120 \mathrm{~min}$, indicating serious hemolysis. Hence, we carried out the subsequent experiments using hyperthermia $\left(42^{\circ} \mathrm{C}\right)$ for $60 \mathrm{~min}$.

Though hyperthermia $\left(42{ }^{\circ} \mathrm{C}\right.$ for $\left.60 \mathrm{~min}\right)$ itself did not completely eliminate HepG2 cells in the current study, a combination of hyperthermia and chemotherapy has already been reported to effectively inhibit tumor cells (Issels, 2008). It is known that the cytotoxic effect of platinum compounds, commonly used in chemotherapy, is linearly enhanced with increasing temperature from $37{ }^{\circ} \mathrm{C}$ to over $40^{\circ} \mathrm{C}$ (Westermann et al., 2001). Cisplatin is a broad-spectrum anticarcinogen, which is also used in combination with hyperthermia (Issels, 2008). The tumor cell inhibition of high doses of cisplatin ( 80 and $120 \mu \mathrm{g} / \mathrm{ml}$ ) at $24 \mathrm{~h}$ in vitro is above $80 \%$ (Hartmann et al., 2014; Su et al., 2012). Anucleated erythrocytes are little damaged by cisplatin in theory because the key molecular target of cisplatin is eukaryotic DNA (Issels, 2008). Here, a combination of cisplatin and hyperthermia has been verified to effectively purge HepG2 cells in erythrocytes.

Cell colony formation and EdU incorporation as a measurement of DNA metabolism are used to evaluate the proliferation capacity of malignant cells. Our results showed that DNA metabolism and colony formation at the 14th day in HepG2 cells $\left(5 \times 10^{4} \mathrm{ml}^{-1}\right.$ mixed in erythrocytes) were totally inhibited by pretreating with a combination of cisplatin $(50,100$, or $200 \mu \mathrm{g} / \mathrm{ml})$ and hyperthermia $\left(42^{\circ} \mathrm{C}\right)$ for $60 \mathrm{~min}$. This result is consistent with that of a previous study showing that the half maximal inhibitory concentration $\left(\mathrm{IC}_{50}\right)$ of cisplatin in human colon cells was about $25 \mu \mathrm{g} / \mathrm{ml}$ (Moretto et al., 2011). However, 
hyperthermia plus cisplatin $(50 \mu \mathrm{g} / \mathrm{ml})$ for $60 \mathrm{~min}$ in the current study did not significantly affect the oxygen-carrying function of erythrocytes. $\mathrm{P}_{50}$ is an index of oxygen affinity (Winslow, 2007) that is influenced by temperature, $\mathrm{pH}$, and ATP concentration, and the key biomarker of oxygen-carrying function in erythrocytes is 2,3-DPG (Winslow, 2007; Wang et al., 2012). The membrane-bound protein $\mathrm{Na}^{+}-\mathrm{K}^{+}$-ATPase maintains a $\mathrm{Na}^{+}$and $\mathrm{K}^{+}$gradient across the plasma membrane and inhibits erythrocytic fragility. This gradient is necessary to preserve the normal morphology and oxygen-carrying function of erythrocytes (Föller et al., 2010). Therefore, preserving $\mathrm{Na}^{+}-\mathrm{K}^{+}$ATPase activity, the 2,3-DPG concentration and the subsequent $\mathrm{P}_{50}$ in erythrocytes might be vital to the application of IBS in cancer surgery. All these erythrocytic parameters were not significantly damaged by hyperthermia plus cisplatin $(50 \mu \mathrm{g} / \mathrm{ml})$. Together with the finding that erythrocytic phosphatidylserine externalization, reflecting disintegration of the membrane phospholipid bilayer (Kiefer and Snyder, 2000; Sachar and Saxena, 2011), did not increase in the hyperthermia plus cisplatin $(50 \mu \mathrm{g} / \mathrm{ml})$ treated group, we suppose that a proper pretreatment with cisplatin combined with hyperthermia might be feasible in the application of IBS to cancer surgery.

We also found that cisplatin $(200 \mu \mathrm{g} / \mathrm{ml})$ combined with hyperthermia for 30 min completely inhibited HepG2 cell proliferation, which is consistent with the study of Zhou et al. (2011). However, this treatment significantly increased erythrocytic fragility, extra-erythrocytic free $\mathrm{Hb}$ and $\mathrm{K}^{+}$levels, and markedly decreased erythrocytic $\mathrm{Na}^{+}-\mathrm{K}^{+}$-ATPase activity and $\mathrm{pH}$. It seems that a high cisplatin concentration combined with hyperthermia $\left(42{ }^{\circ} \mathrm{C}\right)$ for $30 \mathrm{~min}$ was not suitable for eliminating tumor cell contamination from IBS.

\section{Conclusions}

Pretreatment with cisplatin $(50 \mu \mathrm{g} / \mathrm{ml})$ combined with hyperthermia $\left(42{ }^{\circ} \mathrm{C}\right)$ for $60 \mathrm{~min}$ effectively inhibited the survival of HepG2 cells but did not significantly affect erythrocytes in vitro. However, further work in a preclinical in vivo system is needed to evaluate whether this approach is feasible in clinical applications.

\section{Compliance with ethics guidelines}

Jin-ting YANG, Li-hui TANG, Yun-qing LIU, Yin WANG, Lie-ju WANG, Feng-jiang ZHANG, and Min YAN declare that they have no conflict of interest.

All procedures followed were in accordance with the ethical standards of the responsible committee on human experimentation (institutional and national) and with the Helsinki Declaration of 1975, as revised in 2008 (5). Informed consent was obtained from all patients for being included in the study. Additional informed consent was obtained from all patients for whom identifying information is included in this article.

\section{References}

Adias, T.C., Jeremiah, Z., Uko, E., et al., 2006. Autologous blood transfusion - a review. S. Afr. J. Surg., 44(3):114-116, 118.

Catling, S., Williams, S., Freites, O., et al., 2008. Use of a leucocyte filter to remove tumour cells from intra-operative cell salvage blood. Anaesthesia, 63(12):1332-1338. [doi: 10.1111/j.1365-2044.2008.05637.x]

Edelman, M.J., Potter, P., Mahaffey, K.G., et al., 1996. The potential for reintroduction of tumor cells during intraoperative blood salvage: reduction of risk with use of the RC-400 leukocyte depletion filter. Urology, 47(2): 179-181. [doi:10.1016/S0090-4295(99)80411-7]

Föller, M., Braun, M., Qadri, S.M., et al., 2010. Temperature sensitivity of suicidal erythrocyte death. Eur. J. Clin. Invest., 40(6):534-540. [doi:10.1111/j.1365-2362.2010.022 96.x]

Hansen, E., Wolff, N., Knuechel, R., et al., 1995. Tumor cells in blood shed from the surgical field. Arch. Surg., 130(4): 387-393. [doi:10.1001/archsurg.1995.01430040049007]

Hansen, E., Knuechel, R., Altmeppen, J., et al., 1999. Blood irradiation for intraoperative autotransfusion in cancer surgery: demonstration of efficient elimination of contaminating tumor cells. Transfusion, 39(6):608-615. [doi: 10.1046/j.1537-2995.1999.39060608.x]

Harrison, L.E., Bryan, M., Pliner, L., et al., 2008. Phase I trial of pegylated liposomal doxorubicin with hyperthermic intraperitoneal chemotherapy in patients undergoing cytoreduction for advanced intra-abdominal malignancy. Ann. Surg. Oncol., 15(5):1407-1413. [doi:10.1245/s10434007-9718-8]

Hartmann, S., Kriegebaum, U., Küchler, N., et al., 2014. Correlation of MAGE-A tumor antigens and the efficacy of various chemotherapeutic agents in head and neck carcinoma cells. Clin. Oral Investig., 18(1):189-197. [doi:10.1007/s00784-013-0936-0]

Hasegawa, A., Shimizu, R., Mohandas, N., et al., 2012. Mature erythrocyte membrane homeostasis is compromised by loss of the GATA1-FOG1 interaction. Blood, 119(11): 2615-2623. [doi:10.1182/blood-2011-09-382473]

Herron, D.M., Grabowy, R., Connolly, R., et al., 1997. The limits of bloodwarming: maximally heating blood with an 
inline microwave bloodwarmer. J. Trauma, 43(2):219-228. [doi:10.1097/00005373-199708000-00003]

Hildebrandt, B., Wust, P., Ahlers, O., et al., 2002. The cellular and molecular basis of hyperthermia. Crit. Rev. Oncol. Hematol., 43(1):33-56. [doi:10.1016/S1040-8428(01)00 179-2]

Issels, R.D., 2008. Hyperthermia adds to chemotherapy. Eur. J Cancer, 44(17):2546-2554. [doi:10.1016/j.ejca.2008.07. 038]

Jemal, A., Center, M.M., Desantis, C., et al., 2010. Global patterns of cancer incidence and mortality rates and trends. Cancer Epidemiol. Biomarkers Prev., 19(8):1893-1907. [doi:10.1158/1055-9965.EPI-10-0437]

Kiefer, C.R., Snyder, L.M., 2000. Oxidation and erythrocyte senescence. Curr. Opin. Hematol., 7(2):113-116. [doi:10. 1097/00062752-200003000-00007]

Kumar, N., Chen, Y., Zaw, A.S., et al., 2014. Use of intraoperative cell-salvage for autologous blood transfusions in metastatic spine tumour surgery: a systematic review. Lancet Oncol., 15(1):e33-e41. [doi:10.1016/S1470-2045 (13)70245-6]

Moretto, J., Chauffert, B., Ghiringhelli, F., et al., 2011. Discrepancy between in vitro and in vivo antitumor effect of a new platinum(II) metallointercalator. Invest. New Drugs, 29(6):1164-1176. [doi:10.1007/s10637-010-9461-z]

Sachar, S., Saxena, R.K., 2011. Cytotoxic effect of polydispersed single walled carbon nanotubes on erythrocytes in vitro and in vivo. PLoS ONE, 6(7):e22032. [doi:10. 1371/journal.pone.0022032]

Su, X.Y., Yin, H.T., Li, S.Y., et al., 2012. Intervention effects of nedaplatin and cisplatin on proliferation and apoptosis of human tumour cells in vitro. Asian Pac. J. Cancer Prev., 13(9):4531-4536. [doi:10.7314/APJCP.2012.13.9. 4531]

Sugarbaker, P.H., 2007. Laboratory and clinical basis for hyperthermia as a component of intracavitary chemotherapy. Int. J. Hyperthermia, 23(5):431-442. [doi:10.1080/ 02656730701455318]

Wang, X., Ji, B., Zhang, Y., et al., 2012. Comparison of the effects of three cell saver devices on erythrocyte function during cardiopulmonary bypass procedure - a pilot study. Artif. Organs, 36(10):931-935. [doi:10.1111/j.1525-1594. 2012.01494.x]

Waters, J.H., Donnenberg, A.D., 2009. Blood salvage and cancer surgery: should we do it? Transfusion, 49(10): 2016-2018. [doi:10.1111/j.1537-2995.2009.02379.x]

Waters, J.H., Yazer, M., Chen, Y.F., et al., 2012. Blood salvage and cancer surgery: a meta-analysis of available studies. Transfusion, 52(10):2167-2173. [doi:10.1111/j. 1537-2995.2011.03555.x]

Westermann, A.M., Grosen, E.A., Katschinski, D.M., et al., 2001. A pilot study of whole body hyperthermia and carboplatin in platinum-resistant ovarian cancer. Eur. $J$. Cancer, 37(9):1111-1117. [doi:10.1016/S0959-8049(01)
00074-0]

Winslow, R.M., 2007. The role of hemoglobin oxygen affinity in oxygen transport at high altitude. Respir. Physiol. Neurobiol., 158(2-3):121-127. [doi:10.1016/j.resp.2007. 03.011]

Wu, J.B., Lei, W.F., Zhao, L.Y., et al., 2006. Hyperthermia: its effectiveness in killing tumor cells and influence on $\mathrm{Na}^{+}-\mathrm{K}^{+}$-ATPase activities in erythrocytes. Chin. J. Anesthesiol., 26(3):258-260 (in Chinese).

Zhou, J.F., Wang, P., Lei, W.F., 2011. Effectiveness of cisdiamminedichloroplatinum combined with hyperthermia in killing liver tumor cells and its influence on erythrocytes in vitro. Chin. J. Anesthesiol., 31(2):193-196 (in Chinese).

\section{中文概要}

\section{题 目: 顺铂联合热处理对术中回收血红细胞及其中混杂 的肝肿瘤细胞株 (HepG2) 的影响}

目 的: 研究离体热处理和顺铂联合热处理对术中回收血 红细胞功能的影响及其中混杂的肝肿瘤细胞株 (HepG2) 的杀灭作用。

创新点：（1）采用多种评价指标研究了不同时间离体热 处理对术中回收血中混杂的 HepG2 的杀灭作用 及对红细胞的影响, 并确定了对红细胞安全且能 有效杀灭 HepG2 的离体热处理时间。（2）从多 个角度评价了离体顺铂联合热处理对术中回收 血红细胞的影响及对其中混杂的 HepG2 的杀灭 作用, 确定了该方案中对红细胞安全且能有效去 除 HepG2 的顺铂浓度。

方 法: 采用 3-(4,5-二甲基噻唑-2)-2,5-二苯基四氮唑溴盐 （MTT）、5-乙炔基-2'脱氧尿嘧啶核苷（EdU） 和平板克隆形成评估 HepG2 的细胞存活率、DNA 复制率和克隆形成能力（图 1 和 3); 从红细胞 渗透脆性、携氧能力 (2,3-二磷酸甘油酸 (2,3-DPG) 、半饱和氧分压 $\left.\left(\mathrm{P}_{50}\right)\right)$ 、能量代 谢 $\left(\mathrm{Na}^{+}-\mathrm{K}^{+}\right.$-ATPase、 $\mathrm{pH}$ ) 、膜完整性（游离血 红蛋白 $(\mathrm{Hb})$ 、血清 $\mathrm{K}^{+}$和 $\mathrm{Na}^{+}$浓度、细胞膜磷脂 酰丝氨酸外翻比例) 等角度评估红细胞功能

（图 2 和 4; 表 3）。

结 论: 肝肿瘤术中回收血经离体顺铂联合热处理 $\left(42{ }^{\circ} \mathrm{C}\right.$, $50 \mu \mathrm{g} / \mathrm{ml}) 60 \mathrm{~min}$ 后, 能有效清除其中混杂的 HepG2, 但对红细胞无显著影响, 值得体内进一 步研究顺铂热处理有效应用于肿瘤手术自体血 液回输的安全方案。

关键词: 红细胞; HepG2 细胞株; 术中血液回收; 顺铂; 热处理 